\title{
PREVALENCE AND PATTERN OF CANNABIS ABUSE IN A RURAL AREA OF PUNJAB
}

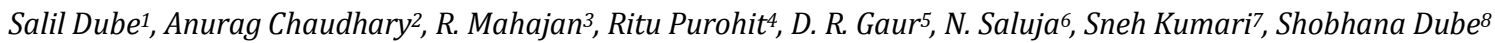 \\ ${ }_{1}^{1}$ Associate Professor, Department of Community Medicine, MAMC, Agroha (Hisar), Haryana. \\ 2 Professor and HOD, Department of Community Medicine, DMC and H, Ludhiana. \\ 3 Professor and HOD, Department of Psychiatry, DMC and H, Ludhiana. \\ ${ }^{4}$ Associate Professor, Department of Physiology, MAMC, Agroha (Hisar), Haryana. \\ 5 Professor, Department of Community Medicine, MAMC, Agroha (Hisar), Haryana. \\ ${ }^{6}$ Associate Professor, Department of Community Medicine, MAMC, Agroha (Hisar), Haryana. \\ ${ }^{7}$ Assistant Professor, Department of Community Medicine, MAMC, Agroha (Hisar), Haryana. \\ ${ }^{8}$ Associate Professor, Department of Ophthalmology, Carrier Institute of Medical Sciences, Lucknow, Uttar Pradesh.
}

\section{ABSTRACT}

\section{BACKGROUND}

About 190 million people all over the world consume one drug or the other. Drug abuse causes immense human distress and the illegal production and distribution of drugs have spawned crime and violence worldwide. Today, there is no part of the world that is free from the curse of drug trafficking and drug abuse. Drug abuse and drug dependence is showing an increasing trend worldwide. Keeping these points in view, this study was conducted with following objectives: a) To find out the prevalence of cannabis abuse in a rural area of Punjab; b) To assess pattern of cannabis abuse in a rural area of Punjab.

\section{MATERIALS AND METHODS}

This is a community based cross-sectional study conducted in the field practice area of Department of Community Medicine, Dayanand Medical College and Hospital, Ludhiana (i.e. Rural Health Training Centre (RHTC) located at village Pohir, Block Dehlon, District Ludhiana, Punjab). One thousand seven hundred and thirty two study subjects of fifteen years and above were included in the study. Primary tools in this study were predesigned and pretested interview scheduled and Alcohol, Smoking and Substance Involvement Screening Test V3 (ASSIST V3) to collect individual information personally in local language. Study subjects were selected from 15 villages covered under RHTC. The statistical analysis was done in proportions.

\section{RESULTS}

In this study $12.39 \%$ individuals of the total population were surveyed, had consumed cannabis during the past 12 months. Study subjects who consumed cannabis for the first time were $76.67 \%$ in the age group of 15 - 24 years, whereas $11.67 \%$ subjects consumed cannabis before or at the age of 15 years.

\section{CONCLUSION}

This study reflects the need to intensify efforts at the community level to protect productive age group from the evil of can nabis abuse.

\section{KEYWORDS}

Cannabis Abuse, Cross-Sectional Study.

HOW TO CITE THIS ARTICLE: Dube S, Chaudhary A, Mahajan R, et al. Prevalence and pattern of cannabis abuse in a rural area of Punjab. J. Evolution Med. Dent. Sci. 2017;6(26):2187-2191, DOI: $10.14260 / J e m d s / 2017 / 474$

\section{BACKGROUND}

"Drug abuse" is defined as self-administration of a drug for non-medical reasons, in quantities and frequencies which may impair an individual's ability to function effectively and which may result in social, physical or emotional harm.(1) About 190 million people all over the world consume one drug or the other. Drug abuse causes immense human distress and the illegal production and distribution of drugs have spawned crime and violence worldwide.

Financial or Other, Competing Interest: None.

Submission 03-01-2017, Peer Review 18-03-2017,

Acceptance 24-03-2017, Published 30-03-2017.

Corresponding Author:

Dr. Salil Dube,

Department of Community Medicine,

Maharaja Agrasen Medical College,

Agroha (HISAR), Haryana.

E-mail: drsalildube@yahoo.co.in

DOI: $10.14260 /$ jemds $/ 2017 / 474$
Today, there is no part of the world that is free from the curse of drug trafficking and drug abuse. (2)

According to estimate by the United Nations on drugs and crime, there were about 200 million people around the world who had used an illicit drug (especially cannabis) by 2001. Most of these were young people, as revealed by data from specific countries.(3)

It has been found in studies from different countries that geographical distribution of drug abuse co-related well with the availability of drugs. The geographical location of India between the Golden Triangle (Burma, Laos and Thailand) and Golden Crescent (Afghanistan and Pakistan) makes it a transit point for the trade of various substances.(4)

India has long and varied history of substance use for thousands of years, various drugs have been considered an essential part of Indian religious ceremonies.(5) A number of Hindu saints took cannabis to overcome hunger and thirst, which helped concentration during meditation. Habitual use of opium became popular during Mughal period (sixteenth century).(6) 
The annual global prevalence rate of illicit drugs consumption, based on UNDCP estimates is likely to be in the range of $3.3 \%$ to $4.1 \%$ of the total population (World Drug Report, 1997). The most widely abused drug is cannabis, which is consumed by $2.5 \%$ (140 million people worldwide). In comparison to the main illicit psychoactive substances, tobacco and alcohol, which are consumed by at least $20 \%$ and $50 \%$ of the world's population respectively.(7)

Cannabis is by far the most widely cultivated, trafficked and abused illicit drug. Half of all drug seizures worldwide are cannabis seizures. The geographical spread of those seizures is also global, covering practically every country of the world. About 147 million people, i.e. $2.5 \%$ of the world population consume cannabis (annual prevalence) compared with $0.2 \%$ consuming cocaine and $0.2 \%$ consuming opiates. The most rapid growth in cannabis abuse since the 1960s has been in developed countries in North America, Western Europe and Australia. Cannabis has become more closely linked to youth culture and the age of initiation is usually lower than for other drugs. An analysis of cannabis markets shows that low prices coincide with high levels of abuse.(8)

Drug Abuse Monitoring System (DAMS) collected data from treatment centres of 23 states, 2 Union territories and Delhi (2002). Total sample of users was 16942. According to study, the mean average age was 35.3 , sample for study was equally distributed in rural (51.7\%) and urban area (48.3\%). For both rural and urban areas, most common substance was alcohol (43.9\%), heroin (11.1\%), cannabis (11.1\%), opium (8.61\%), propoxyphene $(2.6 \%)$ and others $(18.5 \%)$. Others includes tobacco and non-narcotic analgesics.

Surveys in three Northern Indian states in 1989 and 1991 (Indian Council of Medical Research, 1993) found a lifetime prevalence rate of 3 percent and a prevalence of current use of 1 percent with no evidence of any increase between 1989 and 1991. A study conducted among 4326 college students in Varanasi revealed that overall cannabis use among them was 4.5 percent. ${ }^{(9)}$

According to World Drug Report (2009), there were $25,71,52582$ alcohol users, alcohol dependents were $8,22,88826$. Cannabis users were $82,28,883$ and opiate users were 2,057,221 in India.(10)

The problem in recent times has assumed dangerous proportions. Among young people, the drug abuse has become more or less a part of their subculture. Millions of drug addicts all over the world are leading miserable lives between life and death.(11)

Drug abuse and drug dependence is showing an increasing trend. As a developing country, India is very much in the phase of these processes and the trends of drug abuse and dependence need to be watched.(12)

As lot of changes have occurred in the last two decades and variations in consumption patterns is present in different regions, thus the findings of studies conducted earlier and at distant places may not be of much interest in the present scenario. Hence, the present study was carried out to assess the prevalence and pattern of cannabis abuse in a rural area of Ludhiana, Punjab.

\section{Aims and Objectives}

To assess the prevalence of cannabis abuse in a rural area of Punjab and to study the pattern of cannabis abuse in a rural area of Punjab.

\section{MATERIALS AND METHODS}

\section{Study Design}

Community based cross-sectional study.

\section{Setting}

Rural field practice area (Pohir) of Department of Community Medicine, Dayanand Medical College and Hospital, Ludhiana, Punjab.(13)

\section{Participants}

Individuals aged 15 years and above residing in selected households.

\section{Sample Size Estimation}

Sample size estimation was done on the basis of prevalence of substance abuse. As per literature search and a pilot study conducted in the field practice area of Department of Community Medicine, Dayanand Medical College and Hospital, Ludhiana, prevalence of substance abuse ranged from 5 - 54\%. Thus taking a middle course of 32\% prevalence and $10 \%$ of permissible level of error, sample size was calculated as 850 . Overall, 1732 study subjects were included in this study.

For selection of study subjects, field practice area was stratified into 5 strata on the basis of socioeconomic status as per Udai Pareek Classification.(14) The required study subjects were selected adopting probability proportion to sampling size technique.

In order to get required study subjects (1732), simple random sampling was done.

\section{Tools and Technique}

Subjects were interviewed personally in local language through oral questionnaire method and desired information was collected on pre-designed, pre-tested interview schedule and ASSIST V3.0.(15)

The data collected were tabulated and analysed. The statistical analysis was performed by using Microsoft Excel and Epi Info (version 3.5.1).

\section{RESULTS}

Increase in prevalence of cannabis abuse was seen in 15 to 44 years of age group. Males were predominantly abusing cannabis. Religion wise cases of Hindu community were $18.60 \%$. Approximately same figures of prevalence was found $(15.71 \%)$ in scheduled caste and $(9.85 \%)$ in non-schedule caste.

The maximum number of cases $(22.23 \%)$ were nonPunjabi by nativity. It was observed that $68.34 \%$ cases were married. Out of 60 cases $73.34 \%$ cases were having primary education, followed by cases having no education (25.00\%). Majority $(40.00 \%)$ of cases were labourers. Considerable number $(75.00 \%)$ belonged to family income of Rs. 1001 10000. Age of initiation of cannabis abuse was maximum $(76.67 \%)$ in age group of 15 - 24, i.e. productive age group. Friends as company of initiation of cannabis abuse were $91.67 \%$. For initiation of cannabis abuse, peer pressure accounted for $41.67 \%$ cases followed by $38.34 \%$ cases who wanted to start with cannabis and $20.00 \%$ cases tried out of curiosity. Maximum number $(68.34 \%)$ of cases along with friends regularly abused cannabis followed by $28.34 \%$ cases who had abused cannabis all alone in their houses. 
Majority (71.67\%) had no awareness regarding harmful effects of cannabis abuse.

\begin{tabular}{|c|c|c|}
\hline $\begin{array}{l}\text { Socio-Economic } \\
\text { Status Group }\end{array}$ & $\begin{array}{l}\text { Number of } \\
\text { Subjects }\end{array}$ & $\begin{array}{l}\text { Percentage } \\
(\%)\end{array}$ \\
\hline High & 90 & 5.20 \\
\hline High Middle & 608 & 35.10 \\
\hline Middle & 574 & 33.14 \\
\hline Lower Middle & 426 & 24.60 \\
\hline Lower & 34 & 1.96 \\
\hline Total & 1732 & 100 \\
\hline \multicolumn{3}{|c|}{$\begin{array}{c}\text { Table 1. Distribution of Study Subjects } \\
\text { according to their Socioeconomic Status }\end{array}$} \\
\hline
\end{tabular}

\begin{tabular}{|c|c|c|}
\hline Substances Ever Used & Number & Percentage \\
\hline No & 1198 & 69.17 \\
\hline Yes & 534 & 30.83 \\
\hline Table 2. Prevalence of Substance Ever Used (N = 1732) \\
\hline
\end{tabular}

\begin{tabular}{|c|c|c|}
\hline Substance Used & Number & Percentage \\
\hline No & 1248 & 72.05 \\
\hline Yes & 484 & 27.95 \\
\hline \multicolumn{2}{|c|}{ Table 3. Prevalence of Substance } \\
Abuse* in past 12 Months (N = 1732) $^{2}$
\end{tabular}

\begin{tabular}{|c|c|c|c|c|}
\hline $\begin{array}{c}\text { Sl. } \\
\text { No. }\end{array}$ & $\begin{array}{c}\text { Age } \\
\text { (Years) }\end{array}$ & Number & $\begin{array}{c}\text { Prevalence of } \\
\text { Substance } \\
\text { Abuse (\%) }\end{array}$ & $\begin{array}{c}\text { Cannabis Abuse } \\
\text { in Past } 12 \\
\text { Months (\%) }\end{array}$ \\
\hline 1 & $15-24$ & $\begin{array}{c}453 \\
(100)\end{array}$ & $\begin{array}{c}55(100) \\
(12.14)\end{array}$ & 06 (10.91) \\
\hline 2 & $25-34$ & $\begin{array}{c}359 \\
(100)\end{array}$ & $\begin{array}{c}100(100) \\
(27.86)\end{array}$ & $15(15.00)$ \\
\hline 3 & $35-44$ & $\begin{array}{c}298 \\
(100)\end{array}$ & $\begin{array}{c}99(100) \\
(33.22)\end{array}$ & 17 (17.17) \\
\hline 4 & $45-54$ & $\begin{array}{c}251 \\
(100)\end{array}$ & $\begin{array}{l}96(100) \\
(38.25)\end{array}$ & 09 (09.37) \\
\hline 5 & $55-64$ & $\begin{array}{c}193 \\
(100)\end{array}$ & $\begin{array}{l}65(100) \\
(33.68)\end{array}$ & 09 (13.84) \\
\hline 6 & $\geq 65$ & $\begin{array}{c}178 \\
(100)\end{array}$ & $\begin{array}{l}69(100) \\
(38.76)\end{array}$ & 04 (05.79) \\
\hline & Total & $\begin{array}{l}1732 \\
(100)\end{array}$ & $\begin{array}{c}484(100) \\
(27.95)\end{array}$ & $60(12.39)$ \\
\hline
\end{tabular}

Figures in the parentheses indicate percentage.

\begin{tabular}{|c|c|c|c|c|c|c|c|}
\hline \multirow{2}{*}{ Sl. No. } & \multirow{2}{*}{ Age (Years) } & \multirow{2}{*}{ Gender } & \multirow{2}{*}{ Number (\%) } & \multicolumn{3}{|c|}{ Prevalence of Substance Abuse } & \multirow{2}{*}{$\begin{array}{c}\text { Cannabis } \\
\text { Abuse in Past } \\
12 \text { Months }\end{array}$} \\
\hline & & & & Total & Number & Percentage & \\
\hline 1 & $15-24$ & $\begin{array}{c}\text { Male } \\
\text { Female }\end{array}$ & $\begin{array}{l}259(100) \\
194(100)\end{array}$ & 55 & $\begin{array}{c}49 \\
6\end{array}$ & $\begin{array}{c}18.92 \\
3.09\end{array}$ & $\begin{array}{c}06(10.91) \\
0\end{array}$ \\
\hline 2 & $25-34$ & $\begin{array}{c}\text { Male } \\
\text { Female }\end{array}$ & $\begin{array}{l}196(100) \\
163(100)\end{array}$ & 100 & $\begin{array}{c}99 \\
1\end{array}$ & $\begin{array}{c}50.51 \\
0.61\end{array}$ & $\begin{array}{c}15(15.00) \\
0\end{array}$ \\
\hline 3 & $35-44$ & $\begin{array}{c}\text { Male } \\
\text { Female }\end{array}$ & $\begin{array}{l}141(100) \\
157(100)\end{array}$ & 99 & $\begin{array}{c}97 \\
2\end{array}$ & $\begin{array}{c}68.79 \\
1.27\end{array}$ & $\begin{array}{c}17(17.17) \\
0\end{array}$ \\
\hline 4 & $45-54$ & $\begin{array}{c}\text { Male } \\
\text { Female }\end{array}$ & $\begin{array}{l}135(100) \\
116(100)\end{array}$ & 96 & $\begin{array}{c}94 \\
2\end{array}$ & $\begin{array}{c}69.63 \\
1.72\end{array}$ & $\begin{array}{c}09(09.37) \\
0\end{array}$ \\
\hline 5 & $55-64$ & $\begin{array}{c}\text { Male } \\
\text { Female }\end{array}$ & $\begin{array}{c}93(100) \\
100(100)\end{array}$ & 65 & $\begin{array}{c}64 \\
1\end{array}$ & $\begin{array}{c}68.82 \\
1.00\end{array}$ & $\begin{array}{c}09(13.84) \\
0\end{array}$ \\
\hline 6 & $\geq 65$ & $\begin{array}{c}\text { Male } \\
\text { Female }\end{array}$ & $\begin{array}{l}99(100) \\
79(100)\end{array}$ & 69 & $\begin{array}{c}69 \\
0\end{array}$ & $\begin{array}{c}69.70 \\
0\end{array}$ & $\begin{array}{c}04(05.79) \\
0\end{array}$ \\
\hline \multicolumn{2}{|c|}{ Total } & $\begin{array}{c}\text { Male } \\
\text { Female }\end{array}$ & $\begin{array}{l}923(100) \\
809(100)\end{array}$ & 484 & $\begin{array}{c}472 \\
12\end{array}$ & $\begin{array}{c}51.14 \\
1.48\end{array}$ & $\begin{array}{c}60(12.39) \\
0\end{array}$ \\
\hline
\end{tabular}

Figures in the parentheses indicate percentage.

\begin{tabular}{|c|c|c|c|}
\hline \multirow{2}{*}{ Religion } & \multicolumn{2}{|c|}{ Prevalence } & $\begin{array}{c}\text { Pattern of Substances } \\
\text { Used in Past 12 Months }\end{array}$ \\
\cline { 2 - 4 } & Number & Percentage & Cannabis \\
\hline $\begin{array}{c}\text { Hindu } \\
(\mathrm{n}=146)\end{array}$ & 43 & 29.45 & $08(18.60)$ \\
\hline $\begin{array}{c}\text { Sikh } \\
(\mathrm{n}=1534)\end{array}$ & 429 & 27.97 & $51(11.89)$ \\
\hline $\begin{array}{c}\text { Muslim } \\
(\mathrm{n}=30)\end{array}$ & 4 & 13.33 & $0(0.00)$ \\
\hline $\begin{array}{c}\text { Others } \\
(\mathrm{n}=22)\end{array}$ & 8 & 36.36 & $01(12.50)$ \\
\hline \multicolumn{3}{|c|}{ Table 6. Religion Wise Prevalence and } \\
Pattern of Substance Abuse in past 12 Months \\
\hline
\end{tabular}

\begin{tabular}{|c|c|c|c|}
\hline \multirow{2}{*}{ Caste } & \multicolumn{2}{|c|}{ Prevalence } & $\begin{array}{c}\text { Pattern of } \\
\text { Substances } \\
\text { used in Past 12 } \\
\text { Months }\end{array}$ \\
\cline { 2 - 4 } & Number & Percentage & Cannabis \\
\hline $\begin{array}{c}\text { Scheduled caste } \\
(\mathrm{n}=682)\end{array}$ & 210 & 30.79 & $33(15.71)$ \\
\hline $\begin{array}{c}\text { Non-Scheduled } \\
\text { caste (n = 1050) }\end{array}$ & 274 & 26.10 & $27(09.85)$ \\
\hline
\end{tabular}

Table 7. Caste Wise Prevalence and Pattern of Drug Abuse in past 12 Months

Figures in the parentheses indicate percentage.

Figures in the parentheses indicate percentage 


\begin{tabular}{|c|c|c|c|}
\hline \multirow{2}{*}{ Nativity } & \multicolumn{2}{|c|}{ Prevalence } & $\begin{array}{c}\text { Pattern of Substances } \\
\text { used in Past 12 Months }\end{array}$ \\
\cline { 2 - 4 } & Number & Percentage & Cannabis \\
\hline $\begin{array}{c}\text { Punjabi } \\
(\mathrm{n}=1703)\end{array}$ & 475 & 27.89 & $58(12.21)$ \\
\hline $\begin{array}{c}\text { Non-Punjabi } \\
(\mathrm{n}=29)\end{array}$ & 9 & 31.03 & $02(22.23)$ \\
\hline \multicolumn{3}{|c|}{ Table 8. Nativity Wise Prevalence and } \\
Pattern of Drug Abuse in past 12 Months \\
\hline
\end{tabular}

Figures in the parentheses indicate percentage.

\section{DISCUSSION}

In present study, the prevalence of ever user (Table 2) was found to be $30.83 \%$. The prevalence of substance abuse in other studies conducted at different places in India have been reported in the range of 5 to $54 \%$. In a study conducted in Agra by Dube and Handa (1971) on drug use in Indian population, higher prevalence rate of drug use $(50.08 \%)$ was found.(16) Another study done by Meena et al in 2002 in Rohtak city studied Prevalence and pattern of alcohol and substance abuse in urban areas and reported a prevalence rate of $19.78 \%$.(4) Naskar et al in 2004 studied some socioeconomic factors on drug abuse among the undergraduate medical students in Calcutta and found prevalence of total drug abusers was 48.9\%.(17) Another study conducted by Juyal et al (2006) on substance use among intercollege students in Dehradun reported the prevalence of substance abuse for ever users as $58.7 \%{ }^{(18)}$ Similar higher percentage $(43.4 \%)$ of substance abuse was reported in 2008 by Sarangi et al in their study on substance abuse among adolescents in urban slums of Sambalpur.(19)

In the present study, $27.95 \%$ had used one or the other substance during the past 12 months (Table 3). Similar findings $(27.9 \%)$ has been reported by Naskar et al (2004),(17) whereas the rate of regular use of substances was found to be $31.3 \%$ by Juyal et al (2006).(18) Comparatively, lower prevalence (18.3\%) was reported in a study conducted by Dube et al (1978) amongst college students.(20) Sethi and Manchanda (1978) studied pattern of drug abuse among male students in Lucknow and categorised $11.5 \%$ students as 'drug abusers.'(21) Study conducted in Punjab by Singh (1978) on drug abuse prevention with special reference to alcohol use reported drug abuse for current users as $20.4 \%(22)$; $21.4 \%$ drug abusers were reported by Sethi and Trivedi in 1979 in a study on drug abuse in rural population of Bantra (Lucknow).(23)

In the study conducted by Meena et al (2002) in urban areas of Rohtak city, prevalence rate of $19.78 \%$ was reported.(4)

There were 484 cases who were consuming one or the other substance, out of which $12.39 \%$ cases were consuming cannabis (Table 4). Bhalla et al in 2006 studied profile of substance abusers using the emergency services in a tertiary care hospital in Sikkim and found alcohol abusers were $77.8 \%$, cannabis $5.6 \%$, heroin $1.97 \%$ and other opioid abusers $14.8 \% .(24)$

In present study (Table 5), it was observed that out of 1732 subjects economically productive age group, i.e. 25 - 54 years comprised of 908 subjects and among them prevalence of substance abuse was found to be $32.49 \%$, whereas a higher prevalence (38.76\%) was observed in the older age group of 65 years and above. It was observed that with increase in age of study group there is gradual increase in prevalence of substance abuse. The pattern of consumption of substance abuse indicates that alcohol was being most commonly consumed in all the age groups followed by tobacco, opioids and cannabis. A study done by Meena et al (2002) in urban areas of Rohtak city observed that $42.41 \%$ of users were in the age group of 25 - 34 years.(4) Singh et al (2004) in a comparative study of prevalence in urban and rural area of Amritsar reported that percentage of the regular users in age bracket of 40 - 49 years and 50 - 59 years were $26.3 \%$ and $71.4 \%$ respectively. In Urban area $87.5 \%$ of users and in rural area $82.9 \%$ of users were consuming alcohol daily.(25) Mohan et al (2004) in study conducted at de-addiction clinic in a Psychiatric Hospital, Jammu, found $59 \%$ of the users belonged to 20 - 30 years of age group and $25 \%$ belonged to 30 - 40 years' age group.(26) Shastri and Kolhatkar (1989) studied socio-demographic features of cannabis and heroin abuse in Bombay and revealed that seventy-two percent of addicts belonged to the age group of $20-24$ years.(27) In 2008 , Sarangi et al conducted a study among adolescents in urban slums of Sambalpur and found prevalence to be $55.2 \%$ in the 16 - 19 years' age group.(19)

\section{CONCLUSION}

Study subjects who consumed cannabis for the first time were $76.67 \%$ in the age group of $15-24$ years, whereas $11.67 \%$ subjects consumed cannabis before or at the age of 15 years. This study reflects the need to intensify efforts at the community level to protect productive age group from the evil of cannabis abuse.

\section{Limitations}

The study is based on interview of the respondent, so misreporting due to recall bias, local customs and taboos could not be ruled out.

\section{Recommendations}

Awareness levels were observed to be less among cases. Information, education and communication programs with aid of folk media, i.e. story telling, puppetry and drama should be planned.

With the help of NGO's, community leaders, religious leaders, community and medical personnel's efforts should be made for reducing the availability and consumption of drugs and launching an effective education and information programme for high lighting the harmful effects of drugs and measures for its control.

The younger generation (productive age group) should be specially targeted, who may be the future drug abusers.

\section{REFERENCES}

[1] Kaplan HI, Sadock BJ, Sadock VA, et al. Kaplan and Sadock's comprehensive text book of psychiatry. 7 th edn. Lippincott Williams \& Wilkins 2000;1: p. 924.

[2] Azad India foundation. Drug abuse in India. 2010. http://www.azadindia.org/social-issues /Drug-Abusein-India.html. 
[3] Department of mental health and substance abuse, Geneva and WHO centre for health development, Kobe, World Health Organization, substance use among young people in urban environment. 2010. http://www.who.int/nmh/en.

[4] Meena, Khanna P, Vohra AK, et al. Prevalence and pattern of alcohol and substance abuse in urban areas of Rohtak city. Indian J Psychiatry 2002;44(4):348-52.

[5] Lal B, Singh G. Alcohol consumption in Punjab. Indian Journal of Psychiatry 1978;20(3):212-16.

[6] WHO. Drug problems in the socio cultural context: a basis for policies and programme planning. Public health papers 73. Geneva: WHO 1980:42-3.

[7] WHO. Model district program for prevention of alcohol and drug problems in the community WHO- NIMHANS collaborative project. 2010. http://www.nimhans.kar.nic.in/deaddiction/lit/Mand ya_distt_WHO.pdf.

[8] Cannabis WHO 2010. http://www.who.int/substance_abuse/facts/cannabis /en/

[9] Gautam S, Gupta ID, Khan A. Clinical practice guidelines for management of cannabis dependence. 2010.

http://www.indianjpsychiatry.org/cpg/cpg2006/CPgmt_11.pdf.

[10] The 2009 world drug report: a response from the international drug policy consortium 2010. http://www.idpc.net/sites/default/files/library/IDPC \%20WDR\%20Response\%202009\%20Final.pdf.

[11] Kaur R, Gulati JK. Drug abuse. Trends and issues. 2010. http://dspace.iimk.ac.in/bitstream/2259/348/1/387395.pdf.

[12] Khan MZ, Krishana KP. Research on drug dependence in India. UNODC bulletin on narcotics. 1982. http://www.unodc.org/unodc/en/data-andanalysis/bulletin/bulletin_1982-0101_2_page004.html

[13] Choudhry A. Annual report of RHTC Pohir DMC Ludhyana, 2007:1.

[14] Pareek U, Trivedi G. Manual of socio economic status scale. Delhi: Manasyan Publishers 1979.
[15] Who assist (alcohol, smoking and substance involvement screening test) V3.0. 2007.

[16] Dube KC, Handa SK. Drug use in health and mental illness in an Indian population. $\mathrm{Br} \mathrm{J}$ Psychiatry 1971;118(544):345-6.

[17] Naskar NN, Roy M, Bhattacharya SK. A study of some socio economic factors on drug abuse among the undergraduate medical students in Calcutta. Indian of Comm Med 2004;29(2):69-71.

[18] Juyal R, Bansal R, Kishore S, et al. Substance use among intercollege students in district Dehradun. Indian Journal of Community Medicine 2006;31(4):252-54.

[19] Sarangi L, Acaraya HP, Panigrahi OP. Substance abuse among adolescents in urban slums of Sambalpur. Indian Journal of Community Medicine 2008;33(4):265-7.

[20] Dube KC, Kumar A, Kumar N, et al. Prevalence and pattern of drug use amongst college students. Acta Psychiatr Scand 1978;57(4):336-56.

[21] Sethi BB, Manchanda R. Pattern of drug abuse among male students. Indian J Psychiat 1978;20(2):166-73.

[22] Singh G. Issues and approaches in drug abuse prevention with special reference to alcohol use in Punjab. Indian J Psychiat 1978;20(3):217-23.

[23] Sethi BB, Trivedi JK. Drug abuse in rural population. Indian J Psychiat 1997;21:211-6.

[24] Bhalla A, Dutta S, Chakarbarti A. A Profile of substance abusers using emergency services in a tertiary care hospital in Sikkim. Indian J Psychiatry 2006;48(4):243-7.

[25] Singh J, Singh G, Mohan V, et al. A comparative study of prevalence of regular alcohol users among the male individuals in an urban and rural area of Distt. Amritsar, Punjab. 2010. http://www.indmedica.com/journals.php?journalid=7 \&issueid $=50$ \&articleid $=609$ \&action $=$ article .

[26] Mohan C, Dhar V, Lal B. A study of I De- addiction clinic at GMC (Psychiatric Hospital) Jammu (J\&K). Indian J Psychiat Abstract Supplement 2004;34:23.

[27] Shastri SS, Kolhatkar KP. Socio-demographic features of cannabis and heroin abuse in Bombay. J Postgrad Med 1989;35(4):196-8. 